\title{
Metabolites from Wild Potato Inhibit Virulence Factors of the Soft Rot and Blackleg Pathogen Pectobacterium brasiliense
}

\author{
Janak R. Joshi, ${ }^{1}$ Linxing Yao, ${ }^{2}$ Amy O. Charkowski, ${ }^{3}$ and Adam L. Heuberger ${ }^{1,4,+}$ \\ ${ }^{1}$ Department of Horticulture and Landscape Architecture, Colorado State University, Fort Collins, CO 80523, U.S.A. \\ ${ }^{2}$ Analytical Resources Core-Bioanalysis and Omics Center, Colorado State University, Fort Collins, CO 80523, U.S.A. \\ ${ }^{3}$ Department of Agricultural Biology, Colorado State University, Fort Collins, CO 80523, U.S.A. \\ ${ }^{4}$ Department of Soil and Crop Sciences, Colorado State University, Fort Collins, CO 80523, U.S.A.
}

Accepted 16 September 2020.

\begin{abstract}
Potato (Solanum tuberosum L.) is the primary vegetable crop consumed worldwide and is largely affected by bacterial pathogens that can cause soft rot and blackleg disease. Recently, resistance to these diseases has been identified in the wild potato $S$. chacoense, and the mechanism of resistance is unknown. Here, it was hypothesized that $S$. chacoense stems or tubers have unique chemistry that confers resistance to the pathogen Pectobacterium brasiliense through bactericidal, bacteriostatic, or antivirulence activity. Stem and tuber metabolite extracts were collected from $S$. chacoense and tested for effects on Pectobacterium bacterial multiplication rates, and activity and expression of known exoenzymes and virulence genes using $S$. tuberosum extracts as a comparative control. Comparatively, the $S$. chacoense extracts did not affect bacterial multiplication rate; however, they did reduce pectinase, cellulase, and protease activities. The chemical extracts were profiled using a bioassay-guided fractionation, and a nontargeted metabolomics comparison of $S$. chacoense and $S$. tuberosum stems and tubers was performed. The data showed that selected alkaloids, phenolic amines, phenols, amines, and peptides are integrative chemical sources of resistance against the bacteria.
\end{abstract}

Keywords: Pectobacterium, potato, potato metabolomics, soft rot resistance

Potato (Solanum tuberosum) is an adaptable plant, a nutritional food, and the most common vegetable crop consumed worldwide (Jansky et al. 2019; Levy and Veilleux 2007). Cultivated potato is susceptible to many diseases, including blackleg, aerial stem rot, and soft rot caused by Pectobacterium spp. (Ma et al. 2007; Mansfield et al. 2012). Blackleg disease occurs when potato stems sprout from a Pectobacterium-

${ }^{\dagger}$ Corresponding author: A. L. Heuberger; Adam.Heuberger@ colostate.edu

Funding: Support was provided by the National Institute of Food and Agriculture grant number COL0-2017-03223.

*The $\boldsymbol{e}$-Xtra logo stands for "electronic extra" and indicates that supplementary materials are published online.

The author(s) declare no conflict of interest.

(C) (1) $(9)$ Copyright $\odot 2021$ The Author(s). This is an open access article Copyright $\odot 2021$ The Author(s). This is an open access article
distributed under the CC BY-NC-ND 4.0 International license. infected tuber, resulting in stem necrosis, leaf chlorosis, and wilting that decimates the crop within 2 months of planting. Aerial stem rot is infection of potato vines and is usually associated with previous physical vine damage, while soft rot is the decay of tubers infected with Pectobacterium spp. that can occur in seed tubers or in daughter tubers during plant growth, or during storage and transit. There are at least 18 Pectobacterium spp., and some species are more often associated with blackleg or with soft rot (Charkowski 2018; Khadka et al. 2020; Li et al. 2019).

Genus Pectobacterium is a broad-host-range necrotrophic pathogen that infects many crops in addition to potato (Ma et al. 2007) and, because of the large losses caused by this pathogen and the threat it imposes to agriculture, it was listed among the top 10 most relevant plant-pathogenic bacteria (Mansfield et al. 2012). Disease control measures in potato and other crops include limited generation production schemes, seed indexing, copper sprays, and sanitation. Other methods such as antibiotics, inorganic and organic salts, chlorine-based compounds, heat, and biological control have been proposed but they do not provide economical and effective disease management (Czajkowski et al. 2011; Motyka et al. 2017).

The major virulence factors of Pectobacterium spp. are secreted enzymes that rapidly degrade plant cell walls; specifically, pectinases, hemicellulases, and proteases (Charkowski et al. 2012). These enzymes degrade the middle lamella and primary plant cell walls, causing the plant cell to lyse (due to turgor pressure), resulting in the wilting and rotting symptoms typical of Pectobacterium infection. Therefore, the bacterial cells are necrotrophic, because they metabolize the plant cell wall components and intracellular contents. Furthermore, Pectobacterium spp. tightly regulate production of plant cell walldegrading enzymes via quorum sensing (QS) (Liu et al. 2008). Moreover, plant cell wall-degrading enzyme activity is induced by plant phenolics, pectin fragments, and DNA-damaging agents (Charkowski et al. 2012; Liu et al. 1997). Disease caused by Pectobacterium spp. initiates when the pathogen develops into a virulent state, and this process is controlled through interactions with external signals from the host or neighboring pathogens.

Although resistance to Pectobacterium in Solanum spp. is limited, it is possible that plants restrict disease through production of phytoalexins or phytoanticipins. Solanum spp. produce rishitin, a terpene phytolexin that modifies the outer surface of Pectobacterium cells and, at higher concentrations, rishitin causes holes to form in bacterial cell membranes (Robertson et al. 1985). Much remains to be learned about 
the role of phytoalexins in conferring resistance and much of the available data remains correlative (Hildenbrand and Ninnemann 1994). For example, three novel plant flavonoids are induced in Pectobacterium-resistant Ornithogalum lines after inoculation with Pectobacterium spp., but the function of these compounds in disease resistance remains unknown (Yedidia et al. 2019).

Solanaceous species also produce phytoanticipins, which are preformed metabolites (small molecules, generally less than $1,500 \mathrm{Da}$ ) that are toxic to many pathogens and pests. Potato plants produce these protective metabolites in both tubers and stems, including steroidal alkaloids (glycoalkaloids), steroidal glycosides (saponins), phenolics, amino glycosides, polyamine alkaloids (kukoamines), and tropane alkaloids (calystegines) (Chaparro et al. 2018; Friedman 2006). Phytoanticipins act as bioactive metabolites and provide protection by either acting as toxins or interrupting virulence pathways. For example, glycoalkaloids and saponins are directly toxic toward pests and herbivores by inhibiting proteinase activity and interrupting the integrity of animal gut membranes (Hussain et al. 2019). In contrast, phenolics and their derivatives are generally nonlethal but, instead, interfere with virulence signaling pathways of species of Phytophthora, Verticillium, Pectobacterium, Burkholderia, Aliivibrio, Agrobacterium, Chromobacterium, Pectobacterium, and Dickeya (Joshi et al. 2015, 2016; MuñozCazares et al. 2017). In these pathogens, potato phenolics can specifically affect microbial pigment, biofilm, motility, exoenzyme, and QS pathways (Compean and Ynalvez 2014; Joshi et al. 2015; Othman et al. 2019; Silva et al. 2016). Likewise, alkaloids and terpenoids were shown to have antimicrobial and antivirulence activity against many gram-negative and grampositive bacteria (Cushnie et al. 2014; Guimarães et al. 2019; Silva et al. 2016).

Several accessions of wild potato species have been demonstrated to be resistant or tolerant to Pectobacterium diseases. Here, we hypothesized that tubers and stems of domestic and wild potato differ in their profile of antimicrobial metabolites, and that metabolites contribute to resistance to soft rot disease by acting as toxins (e.g., bactericidal or bacteriostatic), or affect the virulence of these pathogenic bacteria. The lines tested in this study were chosen for their relationship to a diploid potato breeding system that was developed to facilitate genetic mapping and introgression of traits in Solanum species (Leisner et al. 2018; The Potato Genome Sequencing Consortium 2011). As part of this effort, the double monoploid potato line DM1 was generated form $S$. tuberosum group phujera (Paz and Veilleux 1999). DM1 has multiple disabled genes and deleterious alleles (The Potato Genome Sequencing Consortium 2011) and is susceptible to blackleg and soft rot. In contrast, the diploid wild potato $S$. chacoense line M6 is resistant or tolerant to many pathogens and it exhibits high tolerance to Pectobacterium spp. (Chung et al. 2017). We compared metabolite extracts from M6 to those from DM1 for toxicity to Pectobacterium spp. and inhibition of its virulence-related phenotypes to identify potential potato phytoanticipins.

\section{RESULTS}

\section{S. chacoense M6 had reduced Pectobacterium colonization but metabolite extracts did not reduce Pectobacterium multiplication.}

An initial experiment was performed to validate phenotypes in planta, and $S$. tuberosum line DM1 (susceptible potato) and $S$ chacoense M6 (resistant potato) stems were inoculated with red fluorescence protein (RFP)-tagged Pectobacterium brasiliense $\mathrm{Pb} 1692$. Microscopic analysis validated living bacteria in both resistant and susceptible lines; however, DM1 experienced active infections whereas, in M6 plants, the bacterial colonization was comparatively minor (Fig. 1A).

Next, an in vitro experiment was performed to understand whether these infection phenotypes were bactericidal or bacteriostatic and due to the metabolite differences between the two lines. . brasiliense $\mathrm{Pb} 1692$ was cultured in a metabolite extract of DM1 or M6 to determine whether M6 extracts reduced the multiplication rate of $P$. brasiliense. Bacteria were able to multiply using metabolites extracts of both DM1 and M6 (stem and tuber) as metabolic substrates. Except for one time point $(15 \mathrm{~h})$ in the M6 stem extract, $P$. brasiliense multiplication rates were similar in both M6 and DM1 extracts (Fig. 1B).

\section{Metabolite extracts of $S$. chacoense M6 reduced $P$. brasiliense exoenzyme activity and virulence gene expression.}

Effects of metabolite extracts on virulence factors were measured with enzymatic activity and gene expression assays. Compared with DM1 as a susceptible control, M6 stem and tuber metabolites reduced bacterial protease (Prt) and cellulase (Cel) activities, and M6 tuber extracts reduced pectate lyase (Pel) activity (Pel) (Fig. 2A). To investigate the mechanism by which metabolite extracts affected synthesis of these exoenzymes, we assessed the effect of M6 metabolites on the expression of selected genes: pell and pel2 with Pel, prtl and prtE with Prt, prtW and inh with metalloprotease and Prt inhibitor, and $\sec A$ with the protein translocate subunit. The expression of prt1, pel1, and pel2 was reduced in M6 metabolite
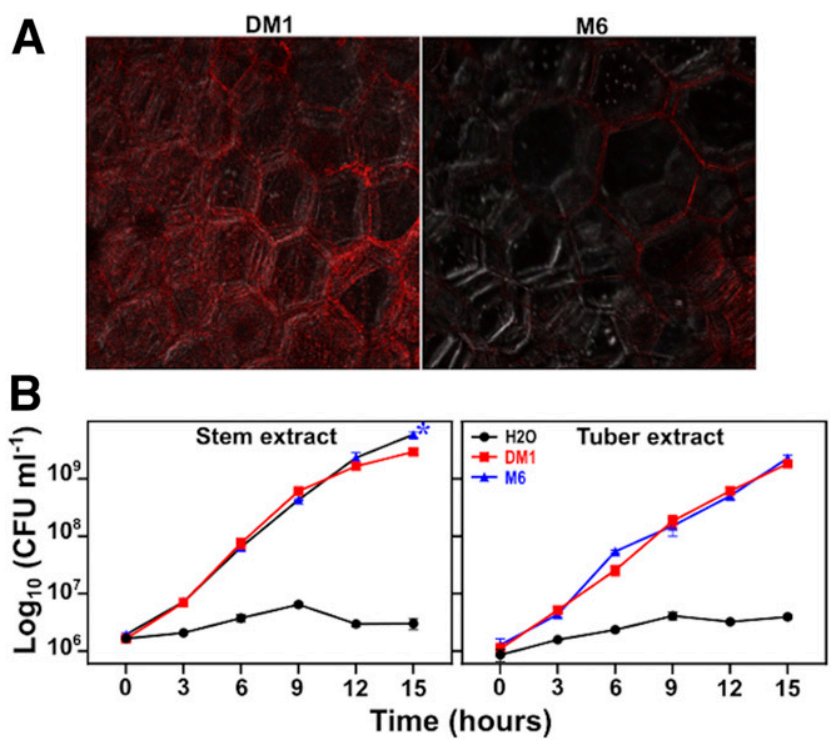

Fig. 1. Colonization and multiplication of Pectobacterium brasiliense $\mathrm{Pb} 1692$. A, Example microscopic observation ( $\times 20$ magnification) of DM1 and M6 potato stem inoculated with red fluorescence protein-tagged $P$. brasiliense $\mathrm{Pb} 1692$. Images were taken after $2 \mathrm{~h}$ of incubating 1-month-old stem cuttings in bacteria suspended in water. B, Multiplication of $P$. brasiliense Pb1692 in metabolite extracts of M6 (blue triangle) or DM1 (red square) stem or tubers or water (black circles) at different time points. Bacteria cultured overnight were adjusted to concentration of $10^{6} \mathrm{CFU} \mathrm{ml}{ }^{-1}$ using sterile water and mixed with metabolite extracts $\left(10 \mu \mathrm{g} \mathrm{ml}^{-1}\right)$ from stem and tuber. Bacteria were then incubated for $15 \mathrm{~h}$ at $28^{\circ} \mathrm{C}$ under continuous shaking. After $0,3,6,9,12$, and $15 \mathrm{~h}$ of incubation, bacterial cells were counted using a serial dilution method and population was expressed as CFU ml $\mathrm{m}^{-1}$. Data shown are the combination of two independent experiments with four replicates in each experiment and presented as mean \pm standard error of the mean. An asterisk (*) indicates significant difference (Student's $t$ test, $P<0.05$ ) in CFU counts between treatments (M6 and DM1 metabolite extracts). 
extracts compared with DM1 extracts (Fig. 2B). In contrast, prtW, inh, and secA gene expression was not different between M6 and DM1 metabolite extracts. Similarly, prtE had lower expression in M6 tuber extracts but the differential expression was not observed in stem extracts (Fig. 2B).

\section{Metabolite extracts of $S$. chacoense M6 reduced}

$P$. brasiliense Pb1692 N-acyl homoserine lactone synthesis.

$\mathrm{N}$-acyl homoserine lactone (AHL) is a signaling molecule used for a bacterial cell-to-cell communication system (i.e., QS) and is required by Pectobacterium spp. for exoenzyme synthesis (de Kievit and Iglewski 2000). To study the effect of metabolite extracts on QS, we assessed the effect on Pectobacterium production of AHL with reporter strain Chromobacterium violaceum CV026. In the presence of external AHL, the reporter strain produced the purple pigment violacein (McClean et al. 1997). Supernatant obtained by growing Pb1692 in M6 metabolite extracts had low AHL compared with DM1, illustrated by lower intensity of purple color in the reporter strain (Fig. 3A). AHL in Pb1692 is synthesized by expI;
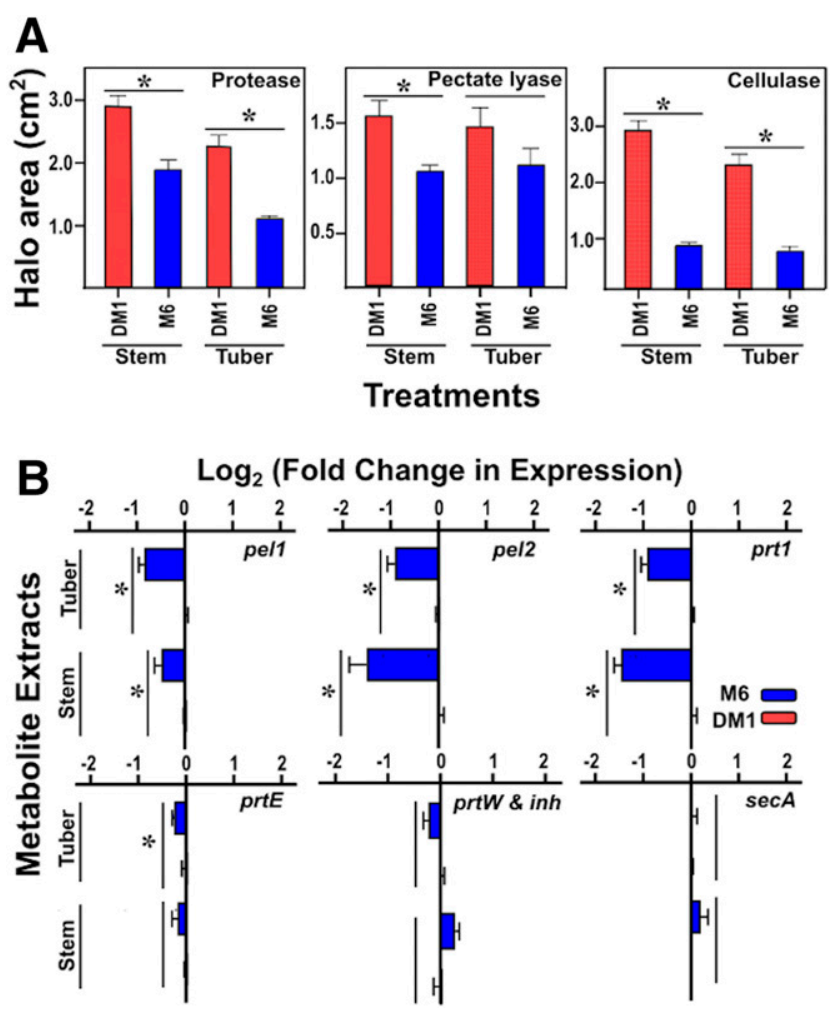

Fig. 2. Effects of M6 and DM1 metabolite extracts on exoenzyme activity and gene expression of Pectobacterium brasiliense Pb1692. A, Enzymatic activity assays after growing bacterial cells $\left(10^{6} \mathrm{CFU} \mathrm{ml^{-1 }}\right)$ in metabolite extracts $\left(10 \mu \mathrm{g} \mathrm{ml}^{-1}\right)$ for $12 \mathrm{~h}$ at $28^{\circ} \mathrm{C}$ under continuous shaking. Data shown are the combination of two independent experiments with four replicates in each experiment and presented as mean \pm standard error of the mean. An asterisk (*) indicates differences between M6 and DM1 treatments (Student's $t$ test, $P<0.05$ ). B, Gene expression analysis of $P$. brasiliense $\mathrm{Pb} 1692$ in response to incubation with metabolite extracts of M6 (blue) and DM1 (red). Bacterial cells $\left(10^{6} \mathrm{CFU} \mathrm{ml}^{-1}\right)$ were grown in metabolite extracts $\left(10 \mu \mathrm{g} \mathrm{ml} l^{-1}\right)$ for $12 \mathrm{~h}$ at $28^{\circ} \mathrm{C}$ and transcript level of pell and pel2 (pectate lyases), prt1 and prtE (proteases), prtW and inh (metalloprotease and protease inhibitor), and secA (secretion system) were determined by quantitative reverse-transcription PCR. The level of transcripts was normalized to housekeeping gene recA and expressed relative to DM1 $\left(\log _{2}\right.$ [relative expression]). Data shown are the combination of two independent experiments with three replicates in each experiment and presented as mean \pm standard error of the mean. An asterisk (*) indicates differences between M6 and DM1 treatments (Student's $t$ test, $P<0.05$ ). therefore, the effect of metabolite extracts was also studied on expI gene expression. M6 metabolite extracts reduced the expression of the gene compared with DM1 metabolites (Fig. 3B).

\section{Fractionation of M6 metabolite extracts and effect on Pectobacterium spp.}

A bioassay-guided fractionation study was used to reduce the complexity of the M6 metabolite extract and identify sets of candidate metabolites that inhibit virulence. In these assays, the M6 stem and tuber extracts were fractionated using solid-phase extraction (between 20 and $100 \%$ acetonitrile [ACN] eluents),
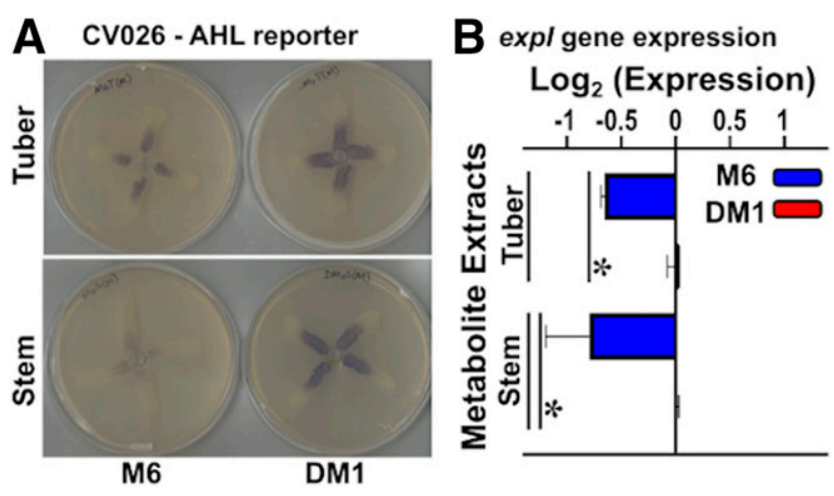

Fig. 3. Effect of DM1 and M6 metabolite extracts on N-acyl homoserine lactone (AHL) of Pectobacterium brasiliense Pb1692. A, Purple color exhibited by CV026 as a response to AHL present in Pb162 grown supernatant. Pictures were taken after incubating the plate at $30^{\circ} \mathrm{C}$ for $18 \mathrm{~h}$. Experiment was repeated three times with similar results. B, expI gene expression analysis of $P$. brasiliense $\mathrm{Pb} 1692$ in response to incubation with metabolite extracts of M6 (blue) and DM1 (red). Bacteria were incubated for $15 \mathrm{~h}$ and transcript levels were determined using quantitative reversetranscription PCR and expressed relative to DM1 ( $\log _{2}$ [relative expression]). Expression was after normalizing to housekeeping gene recA. Data shown are the combination of two independent experiments with three replicates in each experiment and presented as mean \pm standard error of the mean. An asterisk (*) indicates differences between M6 and DM1 treatments (Student's $t$ test, $P<0.05$ ).

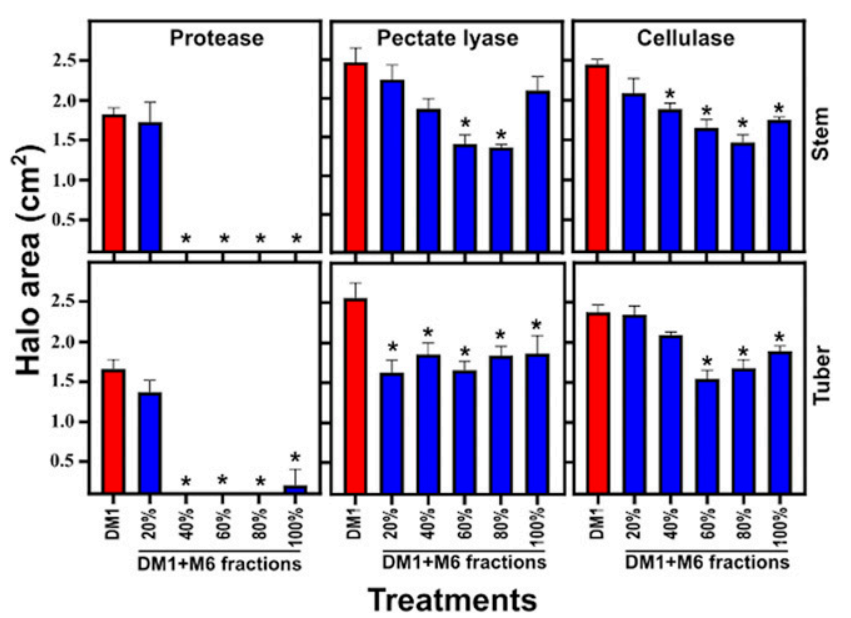

Fig. 4. Exoenzyme activity of Pectobacterium brasiliense Pb1692 in M6 metabolite fractions. Activity assays were performed after growing bacterial cells $\left(10^{6} \mathrm{CFU} \mathrm{ml}{ }^{-1}\right)$ in metabolite extracts for $12 \mathrm{~h}$ at $28^{\circ} \mathrm{C}$ under continuous shaking. Treatments consisted of $5 \mathrm{mg}$ of each M6 fraction (20 to $100 \%$ ) added to $5 \mathrm{mg}$ of the DM1 metabolite extracts for a final concentration of extract at $10 \mathrm{mg} / \mathrm{ml}$. Data shown are the combination of two independent experiments with $n=3$ replicates in each experiment and presented as mean \pm standard error of the mean. An asterisk (*) indicates differences between DM1 + M6 fractions and control DM1 treatments (Dunnett's test, $P<0.05$ ). 
adding portions of the M6 fraction back to DM1, and testing for effects on exoenzyme activity. All M6 fractions eluted at 60 and $80 \%$ ACN significantly inhibited Prt, Pel, and Cel activity (Fig. 4).

\section{Metabolomics analysis of $S$. chacoense extracts using liquid chromatography mass spectrometry.}

A comparative metabolomics experiment was performed to identify pools of metabolites associated with the antivirulence activity in M6 stem and tuber fractions, relative to the metabolite content of DM1. The 60 and $80 \%$ ACN fractions from stem and tuber (denoted S60 and S80 for stem and T60 and T80 for tuber) were evaluated using liquid chromatography mass spectrometry (LC-MS). The metabolomics analysis detected a total of 4,576 metabolites among the four sample types (Fig. 5; Supplementary Material). Principal component analysis (PCA) was performed to characterize metabolites that distinguish M6 and DM1 (Fig. 5A). In total, seven principal components (PCs) were generated that explained $93.2 \%$ of the variation. The first two PCs $(52.7 \%)$ demonstrated metabolite variation influenced by the three main experimental factors: PC1 was mostly influenced by fraction (60 or 80 ) and mildly driven by tissue (stem or tuber), and PC2 was largely influenced by genotype (DM1 or M6).

Because the 60 and $80 \%$ ACN M6 fractions exhibited similar responses to exoenzyme activity (Fig. 3B), and similar response were observed in both stems and tubers extracts (Fig. 3B), metabolites were considered of interest based on the following thresholds: they were (i) common to stems and tubers, (ii) common in the 60 and $80 \%$ fractions, and (iii) more abundant in all M6 tissues and fractions compared with all DM1samples. Metabolites that exhibited this pattern in the data set were determined by correlation-scaling (corr) the PCA loadings, and focused on highly negative corr values for PC2 and loading values centered around zero for PC1. Of the 4,576 metabolites detected in this experiment, 108 metabolites met the thresholds for significance. The 108 metabolites were subsequently annotated and categorized into 11 ontological classes (Table 1) based on their chemistry. Several classes are known to contain compounds with demonstrated antimicrobial activity, including steroidal alkaloids (herein synonymous with "glycoalkaloids" discussed in the potato plant system), steroidal saponins, tropane and other alkaloids, cyclic peptides, and phenolics.

The 108 metabolites were then analyzed for fold-change (FC) and pairwise comparisons to quantify the magnitude differences between M6 and DM1 (Table 1; Fig. 5B). Because potato tubers are swollen underground stems, and these metabolomics data were not heavily influenced by tissue type (Fig. 5A), we combined the stem and tuber metabolite data from each fraction independently in both potato species prior to further analysis. Overall, $45 \%(2,060$ of 4,576) of the features were more abundant $\left(P \leq 0.05 ; \log _{2} \mathrm{FC}>1\right)$ in the $60 \% \mathrm{M} 6$ fraction compared with $60 \%$ DM1 fraction (Fig. 5B). Similarly, $44 \%(2,003$ of 4,576) of the features were more abundant in the $80 \%$ M6 fraction (Fig. 5C). Most of the 108 exoenzymeassociated metabolites determined from the PCA were also observed as significant in this univariate analysis (95 of 108).

The 108 metabolites were further analyzed for known antimicrobial activities. In total, three $\alpha$ - and $\beta$-steroidal alkaloids were detected and ranged between 2.89- to 7.01-fold higher in M6, and no $\gamma$ forms were detected $(\alpha, \beta$, or $\gamma$ denote three, two, or one saccharide residue conjugated to an alkaloid backbone, respectively). All other classes exhibited similar ranges of $\mathrm{FC}$; for example, saponins (4.36 to 6.39), phenolic amines (1.3 to 5.51 ), phenolics (0.92 to 6.02), organic acid and amines (1.27 to 4.92), peptides (1.12 to 6.11), saccharides (1.63 to 6.86), lipids (1.74 to 7.06$)$, and others and unknowns (0.61 to 6.82).

\section{DISCUSSION}

Genus Pectobacterium causes huge annual losses worldwide in the potato industry (Mansfield et al. 2012). Some wild potato lines, including $S$. chacoense M6, are resistant or tolerant to Pectobacterium spp. (Leisner et al. 2018). In many wild relatives of cultivated crops, disease resistance is correlated with higher content of phenolics, tropane alkaloids, and alkaloids (Friedman 2006; Othman et al. 2019). To define Pectobacterium resistance mechanisms in S. chacoense M6, plant metabolite extracts and their effects on P. brasiliense $\mathrm{Pb} 1692$ multiplication, enzyme activity, and gene expression were studied and compared with extracts from susceptible $S$. tuberosum DM1. Because the pathogen grew as well or better in metabolite extracts from the resistant potato as the susceptible potato, the M6 extracts do not appear to contain bacterial multiplication inhibitors or toxins that affect cell viability. Interestingly, the M6 stem extract had a higher saccharide content than the DM1 stem extract, which may account for the higher bacterial multiplication observed at the last time point of this experiment.
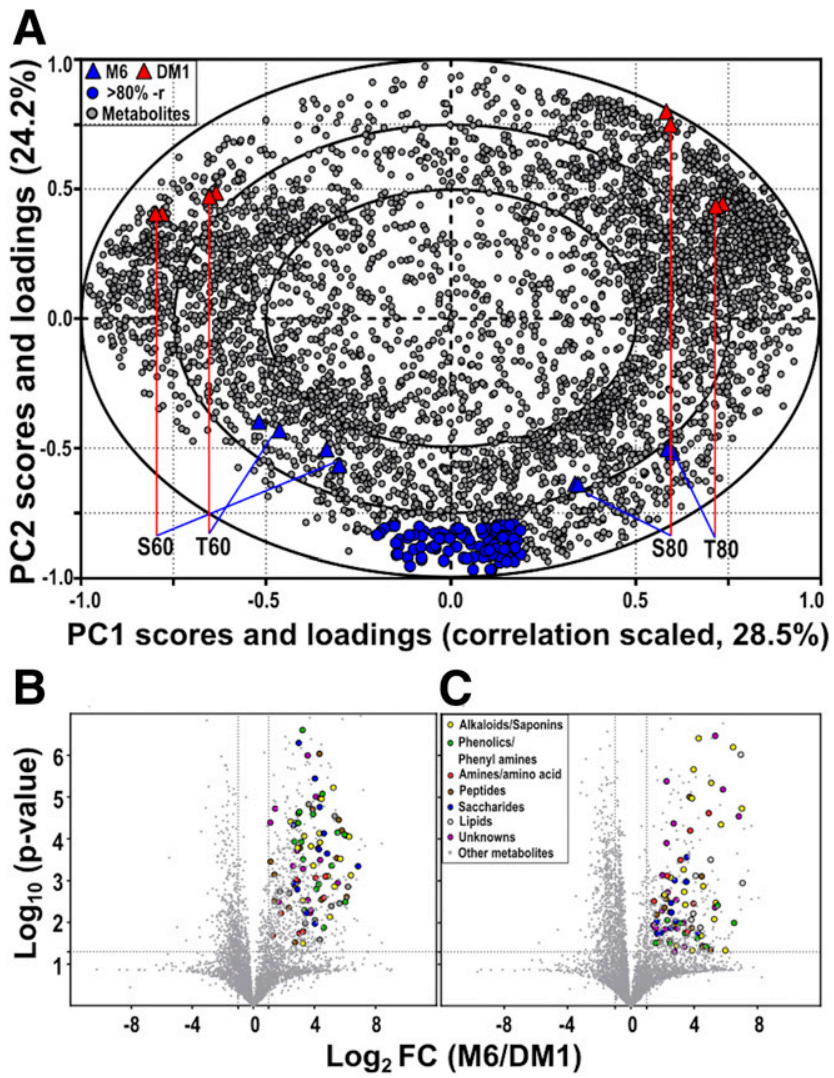

Fig. 5. Principal component analysis (PCA) and volcano plot analysis of potato metabolite fractions. A, Metabolites detected by liquid chromatography mass spectrometry are presented as a biplot of correlated-scaled scores (triangles $=$ stem $[\mathrm{S}]$ and tuber [T] 60 and $80 \%$ fractions) and loadings (circles). Ellipses denote $|0.5|,|0.75|$, and $|1.0|$ correlation values. Data were generated based on 4,576 metabolites among 16 samples. Metabolites represented by blue color (108) were considered to meet the correlation threshold of -0.8 for principal component (PC)2 (positively associated with M6) and centered around 0 for PC1 ( 0.2 threshold to indicate a higher comparative abundance in both stems and tubers, in both 60 and $80 \%$ fractions). $\mathbf{B}$ and $\mathbf{C}$, Volcano plot for the differential abundance $\left(\log _{2}\right.$ M6/DM1, x-axis) and significance $\left(-\log _{10} P\right.$ value, y-axis) of 4,576 metabolites (gray dots) of M6 and DM1 potato. Colored circles represent highly correlated M6 metabolites (0.8/0.2) as determined from PCA. Vertical dashed lines are threshold of M6/DM1 $\left(\log _{2}\right.$ M6/DM1 $<-1$ or $\left.>1\right)$; horizontal dashed line is the threshold for $P$ value at $0.05 . \mathrm{FC}=$ fold change Volcano plots were created for B, $60 \%$ and C, $80 \%$ acetonitrile elution. 


\begin{tabular}{|c|c|c|c|c|}
\hline \multirow[b]{2}{*}{ Superclass, subclass, metabolite ${ }^{a}$} & \multirow[b]{2}{*}{ Identifier $^{\mathrm{b}}$} & \multicolumn{2}{|c|}{$\log _{2}$ FC (M6/DM1) ${ }^{c}$} & \multirow[b]{2}{*}{ Activity $^{\mathbf{d}}$} \\
\hline & & $60 \%$ & $80 \%$ & \\
\hline \multicolumn{5}{|l|}{ Alkaloids } \\
\hline \multicolumn{5}{|l|}{ Steroidal alkaloids } \\
\hline$\alpha$-Solamarine 01 & PHpos_C455 & 3.33 & 3.1 & Cushine et al. 2014 \\
\hline$\alpha$-Solamarine 02 & PHneg_C0282 & 5.7 & 4.57 & Cushine et al. 2014 \\
\hline$\alpha$-Solanine 01 & PHpos_C126 & 3.24 & 3.86 & Cushine et al. 2014 \\
\hline$\alpha$-Solanine 02 & PHpos_C593 & 2.89 & 4.45 & Cushine et al. 2014 \\
\hline$\beta$-Chaconine 01 & HIneg_C0490 & 5.01 & 6.34 & Cushine et al. 2014 \\
\hline$\beta$-Chaconine 02 & HIneg_C0572 & 5.31 & 7.01 & Cushine et al. 2014 \\
\hline$\beta$-Chaconine 03 & PHpos_C413 & 2.43 & 5.37 & Cushine et al. 2014 \\
\hline \multicolumn{5}{|l|}{ Tropane alkaloids } \\
\hline Calystegine A3/A6/A7 & HIneg_C1183 & 3.93 & 3.37 & Christhudas et al. 2012 \\
\hline Calystegine B2/B5 & HIpos_C328 & 3.24 & 3.44 & Christhudas et al. 2012 \\
\hline \multicolumn{5}{|l|}{ Phenolic amines and related } \\
\hline $\begin{array}{l}\text { (2E)-N-(4-acetamidobutyl)-3-(4- } \\
\text { hydroxy-3-methoxyphenyl) } \\
\text { acrylamide }\end{array}$ & PHpos_C322 & 2.3 & $2.17 *$ & Bouarab-Chibane et al. 2019 \\
\hline 4-(2-Nitroethyl) phenyl primeveroside & HIneg_C0563 & 2.93 & $1.3 *$ & Bouarab-Chibane et al. 2019 \\
\hline $\mathrm{N}$-transferuloyloctopamine 01 & HIneg_C0009 & 3.02 & 2.48 & López-Gresa et al. 2011 \\
\hline $\mathrm{N}$-transferuloyloctopamine 02 & PHpos C055 & 3.22 & $1.65 *$ & López-Gresa et al. 2011 \\
\hline $\mathrm{N}$-transferuloyloctopamine 03 & PHneg_C865 & 3.91 & $2.73^{*}$ & López-Gresa et al. 2011 \\
\hline Phenylbutyrylglutamine & HIneg_C0290 & 5.51 & 5.48 & Bouarab-Chibane et al. 2019 \\
\hline \multicolumn{5}{|l|}{ Other alkaloids } \\
\hline Alkaloid 01 & HIneg_C1021 & 2.71 & 2.9 & Cushine et al. 2014 \\
\hline Clavepictine & HIpos_C085 & 4.87 & 6.46 & Cushine et al. 2014 \\
\hline \multicolumn{5}{|l|}{ Amines } \\
\hline \multicolumn{5}{|l|}{ Amino acids } \\
\hline Acetylleucine & HIneg_C1309 & 1.27 & 1.46 & $\ldots$ \\
\hline Arginine & HIneg_C0878 & 2.8 & $1.58^{*}$ & $\ldots$ \\
\hline Proline 01 & HIpos_C265 & $1.51 *$ & 3.13 & Zhang et al. 1999 \\
\hline Proline 02 & HIpos_C332 & $2.3^{*}$ & 2.3 & Zhang et al. 1999 \\
\hline Proline 03 & HIneg_C0833 & 4.72 & 3.96 & Zhang et al. 1999 \\
\hline Valine & HIpos_C527 & 3.01 & 3.57 & $\ldots$ \\
\hline \multicolumn{5}{|l|}{ Lipid amines } \\
\hline N-oleoyl phenylalanine 01 & PHpos_C454 & 3.4 & 3.52 & $\ldots$ \\
\hline N-oleoyl phenylalanine 02 & PHpos_C639 & 5.33 & 4.52 & $\ldots$ \\
\hline \multicolumn{5}{|l|}{ Others } \\
\hline Similar to ecalcidene & HIpos_C560 & 1.81 & 3.75 & $\ldots$ \\
\hline Inosine monophosphate & Phneg_C0614 & 3.23 & 2.49 & $\ldots$ \\
\hline \multicolumn{5}{|l|}{ Organic acids } \\
\hline \multicolumn{5}{|l|}{ Organic acids } \\
\hline L-ascorbic acid-2-glucoside & PHneg_C1316 & 4.08 & $1.56^{*}$ & Verghese et al. 2017 \\
\hline Malic acid & HIneg_C0134 & 4.62 & 4.92 & Raybaudi-Massilia et al. 2009 \\
\hline Phenolics and related & & & & \\
\hline $\begin{array}{l}\text { 3-(2-Methylpropanoyloxy)-8-(2- } \\
\text { methylbutanoyloxy)-9,10-epoxy-p- } \\
\text { mentha-1,3,5-triene }\end{array}$ & HIpos_C137 & 5.97 & 6.52 & Bouarab-Chibane et al. 2019 \\
\hline Coumaric acid & HIneg_C1434 & 4.13 & 3.42 & Lou et al. 2012 \\
\hline Coumarin & PHpos_C562 & 3.25 & $1.8^{*}$ & Bouarab-Chibane et al. 2019 \\
\hline Derricin & PHneg_C1039 & 6.02 & 4.19 & Bouarab-Chibane et al. 2019 \\
\hline Epicatechin methyl gallate & PHneg_C0051 & 4.52 & 2.3 & Nikoo et al. 2018 \\
\hline Ferulic acid & HIneg_C0079 & 3.15 & 3.5 & Borges et al. 2013 \\
\hline Glucocaffeic acid & PHneg_C0877 & 3.34 & 1.57 & $\ldots$ \\
\hline Melanin & HIneg_C0485 & 3.56 & 2.1 & $\ldots$ \\
\hline Phenolic & PHpos_C325 & 2.7 & $0.92 *$ & Bouarab-Chibane et al. 2019 \\
\hline Shikimic acid & HIneg_C1391 & 2.95 & $2.18^{*}$ & Bai et al. 2015 \\
\hline Terezine B/C 01 & PHpos_C776 & 4.61 & 3.11 & Abdou et al. 2020 \\
\hline Terezine $\mathrm{B} / \mathrm{C} 02$ & HIneg_C0185 & 5.13 & 4.76 & Abdou et al. 2020 \\
\hline Terpenes & & & & \\
\hline Steroidal saponins & & & & \\
\hline Graecunin & PHpos_C276 & 4.33 & 3.96 & $\ldots$ \\
\hline Saponin 01 & PHneg_C0221 & $0.86^{*}$ & 2.13 & Soetan et al. 2006 \\
\hline Saponin 02 & PHneg_C0608 & 5.24 & 5.08 & Soetan et al. 2006 \\
\hline Saponin 03 & PHneg_C959 & 2.71 & 2.53 & Soetan et al. 2006 \\
\hline Saponin 04 & HIpos_C142 & 3.77 & 3.88 & Soetan et al. 2006 \\
\hline Torvoside & PHneg_C0112 & 6.39 & 5.97 & $\begin{array}{l}\text { Soetan et al. } 2006 \\
\text { (Continued on next page) }\end{array}$ \\
\hline
\end{tabular}

\footnotetext{
${ }^{a}$ Metabolite annotation based on interpretation of mass spectrometry data. Isomers are indicated by identical spectra but different retention times, denoted as 01,02 , and so on, or potentially the same compound detected on different platforms. Level 3 annotations (denoted simply by a class) are when a spectrum indicates a chemical class but a specific metabolite could not be confidently assigned. $\mathrm{M}=$ neutral mass and nd = annotation could not be determined.

${ }^{\mathrm{b}} \mathrm{PH}=$ phenyl hexyl, $\mathrm{HI}=$ hydrophilic interaction liquid chromatography, pos = positive mode, and neg = negative mode.

${ }^{\mathrm{c}} \log _{2}$ fold-change (FC) values for 60 and $80 \%$ acetonitrile. An asterisk indicates $P>0.05$ and values without an asterisk indicate significant differences between M6 and DM1 at $P<0.05$.

${ }^{\mathrm{d}}$ Reported antimicrobial activity.
} 
Table 1. (Continued from previous page)

\begin{tabular}{|c|c|c|c|c|}
\hline \multirow[b]{2}{*}{ Superclass, subclass, metabolite ${ }^{a}$} & \multirow[b]{2}{*}{ Identifier $^{\mathbf{b}}$} & \multicolumn{2}{|c|}{$\log _{2}$ FC $(\text { M6/DM1 })^{c}$} & \multirow[b]{2}{*}{ Activity ${ }^{d}$} \\
\hline & & $60 \%$ & $80 \%$ & \\
\hline Tuberoside 01 & PHneg_C0111 & 6.27 & 5.27 & Soetan et al. 2006 \\
\hline Tuberoside 02 & PHneg_C0175 & 6.05 & 4.28 & Soetan et al. 2006 \\
\hline Tuberoside 03 & HIneg_C0851 & 4.46 & 3.33 & Soetan et al. 2006 \\
\hline Tuberoside 04 & HIneg_C1184 & 4.36 & 5.69 & Soetan et al. 2006 \\
\hline \multicolumn{5}{|l|}{ Peptides } \\
\hline Cyclic peptide similar to ustiloxin & PHpos_C543 & 3.05 & 1.69 & Jakubczyk and Dussart 2020 \\
\hline $\mathrm{N}$-acetylleucine/acetylisoleucine & HIneg_C1166 & 3.88 & 3.71 & $\ldots$ \\
\hline Peptide 01 & PHneg_C0017 & 6.11 & 1.85 & $\ldots$ \\
\hline Peptide 02 & PHneg_C0178 & 5.8 & 5.03 & $\ldots$ \\
\hline Peptide 03 & PHneg_C0280 & 4.33 & 2.79 & $\ldots$ \\
\hline Peptide 04 & PHneg_C0317 & 5.59 & 4.48 & $\ldots$ \\
\hline Peptide 05 & PHneg_C1323 & 4.46 & $1.57 *$ & $\ldots$ \\
\hline Peptide 06 & PHneg_C0727 & 2.73 & 2.23 & $\ldots$ \\
\hline Peptide 07 & PHneg_C0732 & 1.12 & 2.12 & $\ldots$ \\
\hline Peptide 08 & PHneg_C1032 & 1.38 & 1.62 & $\ldots$ \\
\hline Peptide 09 & PHneg_C0214 & 5.47 & 4.54 & $\ldots$ \\
\hline Peptide 10 & HIneg_C0263 & 2.32 & 2.43 & $\ldots$ \\
\hline Peptide 11 & HIneg_C0226 & 1.38 & 1.62 & $\ldots$ \\
\hline Peptide similar to polyoxin B & HIneg_C0196 & 3.27 & 3.85 & Keymanesh et al. 2009 \\
\hline \multicolumn{5}{|l|}{ Saccharides } \\
\hline \multicolumn{5}{|l|}{ Monosaccharides } \\
\hline Monosaccharide 01 & HIneg_C0579 & 2.62 & $1.19^{*}$ & $\ldots$ \\
\hline Monosaccharide 02 & HIneg_C1337 & 3.45 & 2.77 & $\ldots$ \\
\hline \multicolumn{5}{|l|}{ Disaccharides } \\
\hline Disaccharide 01 & PHpos_C010 & 4.83 & 2.57 & $\ldots$ \\
\hline Disaccharide 02 & PHneg_C0092 & 6.86 & 4.23 & $\ldots$ \\
\hline Disaccharide 03 & PHneg_C0106 & 4.3 & 2.54 & $\ldots$ \\
\hline Disaccharide 04 & HIneg_C0005 & 4.34 & 2.84 & $\ldots$ \\
\hline Disaccharide 05 & HIneg_C0340 & 2.97 & 1.63 & $\ldots$ \\
\hline Disaccharide 06 & HIneg_C1338 & 4.03 & 1.91 & $\ldots$ \\
\hline \multicolumn{5}{|l|}{ Trisaccharides } \\
\hline Trisaccharide-01 & HIneg_C0577 & 4.62 & 3.53 & $\ldots$ \\
\hline Trisaccharides 02 & HIneg_C1343 & $0.02 *$ & $0.19^{*}$ & $\ldots$ \\
\hline \multicolumn{5}{|l|}{ Oligosaccharides } \\
\hline Oligosaccharide & HIneg_C1154 & 4.03 & 3.49 & $\ldots$ \\
\hline Sugar acids & & & & \\
\hline Glucuronic acid & HIneg_C0835 & 2.66 & 2.52 & $\ldots$ \\
\hline Others & & & & \\
\hline $\mathrm{N}$-acetyl-6-O-L-fucosyl-D-glucosamine & HIneg_C1435 & 2.88 & 1.67 & $\ldots$ \\
\hline Lipids & & & & \\
\hline Glycerolipids & & & & \\
\hline PI $(28: 1)$ & HIneg_C0573 & 6.2 & 7.06 & $\ldots$ \\
\hline PI (38:4) & PHpos_C284 & 1.74 & 5.04 & $\ldots$ \\
\hline PS (34:6) & HIneg_C0697 & 5.11 & 6.95 & $\ldots$ \\
\hline PS (42:9) & PHpos_C404 & 2.35 & 4.31 & $\ldots$ \\
\hline Others & & & & \\
\hline 1-Octen-3-yl glucoside & PHneg_C1287 & 4.03 & 4.39 & $\ldots$ \\
\hline Ethyl (S)-3-hydroxybutyrate glucoside & HIneg_C0753 & 4.35 & 3.82 & $\ldots$ \\
\hline Ethyl (S)-3-hydroxybutyrate glucoside & PHneg_C1040 & 5.64 & 4.09 & $\ldots$ \\
\hline Isopentyl gentiobioside & HIneg_C1422 & 3.62 & 3.94 & $\ldots$ \\
\hline $\begin{array}{l}\text { 1,2,10-Trihydroxydihydro-translinalyl } \\
\text { oxide } 7 \text {-O-beta-D-glucopyranoside }\end{array}$ & PHneg_C0619 & 4.09 & 2.7 & $\cdots$ \\
\hline Unknowns & & & & \\
\hline Unknowns & & & & \\
\hline$[\mathrm{M}-\mathrm{H}]^{-}=327.1066$ & HIneg_C0437 & $1.79 *$ & 2.25 & $\ldots$ \\
\hline$[\mathrm{M}-\mathrm{H}]^{-}=605.8024$ & HIneg_C1178 & 3.24 & 2.92 & $\ldots$ \\
\hline$[\mathrm{M}-\mathrm{H}]^{-}=948.4741$ & PHneg_C1031 & 1.42 & 2.25 & $\ldots$ \\
\hline $\mathrm{M}=1043.5921$ & PHpos_C274 & 1.11 & 3.32 & $\ldots$ \\
\hline $\mathrm{M}=1050.5608$ & PHpos_C680 & 5.61 & 5.31 & $\ldots$ \\
\hline $\mathrm{M}=1102.2589$ & HIneg_C0339 & 2.86 & 1.59 & $\ldots$ \\
\hline$M=1572.9533$ & PHneg_C0220 & 5.53 & 6.82 & $\ldots$ \\
\hline$M=294.1313$ & HIneg_C1424 & 3.25 & 2.17 & $\ldots$ \\
\hline $\mathrm{M}=341.1231$ & PHneg_C1280 & 2.91 & 2.87 & $\ldots$ \\
\hline$M=344.1306$ & HIneg_C1444 & 4.36 & 2.76 & $\ldots$ \\
\hline$M=410.0514$ & PHneg_C1286 & 3.77 & 1.49 & $\ldots$ \\
\hline $\mathrm{M}=657.3779$ & PHneg_C1181 & 1.66 & 3.38 & $\ldots$ \\
\hline$M=706.2142$ & PHneg_C0338 & 3.56 & 2.33 & $\ldots$ \\
\hline$M=708.2141$ & PHneg_C1072 & 3.71 & 1.54 & $\ldots$ \\
\hline$M=742.4245$ & HIneg_C1334 & 4.37 & 5.82 & $\ldots$ \\
\hline$M=743.4169$ & HIneg_C0852 & 4.24 & 5.33 & $\ldots$ \\
\hline $\mathrm{M}=897.5098$ & PHneg_C0733 & 0.72 & 1.96 & $\ldots$ \\
\hline $\mathrm{M}=959.5107$ & PHneg_C0516 & 0.61 & 1.41 & $\ldots$ \\
\hline & & & & (Continued on next page) \\
\hline
\end{tabular}


Table 1. (Continued from previous page)

\begin{tabular}{|c|c|c|c|c|}
\hline \multirow[b]{2}{*}{ Superclass, subclass, metabolite ${ }^{a}$} & \multirow[b]{2}{*}{ Identifier $^{b}$} & \multicolumn{2}{|c|}{$\log _{2}$ FC (M6/DM1) ${ }^{c}$} & \multirow[b]{2}{*}{ Activity $^{\mathbf{d}}$} \\
\hline & & $60 \%$ & $80 \%$ & \\
\hline $\mathrm{M}=965.4969$ & PHneg_C0329 & 0.72 & 1.99 & $\ldots$ \\
\hline nd & HIneg_C1283 & 2.65 & $1.84 *$ & $\ldots$ \\
\hline nd & PHneg_C1036 & 2.6 & 1.59 & $\ldots$ \\
\hline
\end{tabular}

M6 metabolite extracts did not reduce bacterial multiplication; therefore, we investigated effects of the extracts on bacterial exoenzyme activity. Pectobacterium spp. secrete Prt, Pel, and Cel to macerate the plant cell wall and to obtain nutrients (Pérombelon 2002). P. brasiliense grown in M6 metabolite extracts had significantly lower Prt, Pel, and Cel activity. Furthermore, gene expression of pel1, pel2, prt1, and prtE demonstrated that these enzymes were downregulated in the presence of M6 extracts, which corresponds with the lower activity observed in the enzyme assays. In addition, M6 metabolite extracts reduced or inhibited AHL synthesis. These results support the idea that M6 resistance to blackleg and soft rot is due, at least in part, to inhibition of bacterial exoenzyme expression via QS inhibition.

Plants are complex organisms producing more than approximately 300,000 metabolites (Wang et al. 2019). This complexity makes it challenging to understand and study specific groups of metabolites that contributed to lower activity of cellwall-degrading enzymes in our study. Therefore, we fractionated the M6 metabolite extracts into five fractions based on polarity. As with whole extracts, none of the fractions reduced bacterial multiplication but only some inhibited exoenzyme activity, with the 60 and $80 \%$ ACN eluted fractions from M6 stems and tubers having the strongest inhibition (Fig. 3). Therefore, these two fractions from stem and tubers were studied independently for their composition using LC-MS. The M6 and DM1 chemical features are distinct from each other. Potato tubers are underground stems; thus, we also compared potato stem and tuber extracts within each potato line and did not find differences. Therefore, the stem and tuber extract data from M6 were combined, as were the stem and tuber extract data from DM1, to provide more statistical power in comparisons between potato lines.

The metabolites that were highly correlated with M6 extracts included saccharides, phenolics, phenyl amines, amino acids, steroidal saponins, alkaloids, peptides, lipids, and organic acids. There were several metabolites which could not be annotated or classified, and these were classified into a single group of unknown metabolites. Among the aforementioned chemical classes, steroidal saponins (torvoside and tuberoside), phenols (ferulic acid and coumarins), and alkaloids (chaconine and solanine) have demonstrated antivirulence or antimicrobial activity against many gram-negative and gram-positive bacteria (Joshi et al. 2015; Othman et al. 2019; Radulović et al. 2013). Further analysis of these metabolites revealed higher content of these chemical classes in M6 than DM1. However, as described above, our multiplication assays did not show evidence of antimicrobial activity but, instead, showed antivirulence properties in these extracts. Such observations might be because of the sublethal concentrations of compounds in the extracts that were used for growing bacteria.

The steroidal and tropane alkaloids detected in our study (calystegines) also have antimicrobial and antivirulence activity against phytopathogens (Friedman 2006; Petersson et al. 2013). These metabolites were found in higher amount in M6 potato. Along with these compounds, higher content of phenols or flavonoid derivatives (coumarins, ferulic acid, shikimic acid, and other phenols) were detected in M6 extracts. These phenolics reduced the virulence of Pectobacterium and Pseudomonas spp. by interfering with the bacterial QS system (Borges et al. 2013; Bai et al. 2015; Joshi et al. 2016; Lou et al. 2012). Similarly, phenolic compounds such as catechin, cinnamaldehyde, coumarin, curcumin, eugenol, quercetin, resveratrol, and salicylic acid interrupt bacterial signaling systems, secretion systems, toxin production, motility, and extracellular enzymes of many gram-negative and grampositive bacteria (Joshi et al. 2020; Muñoz-Cazares et al. 2017). The metabolites in these chemical classes are more abundant in M6 potato, which might contribute to soft rot resistance in M6. In addition, M6 has higher content of lipids, fatty acyls, and peptides. Lipids or fatty acyls destabilize the membrane properties of bacterial cells, leading to direct and indirect inhibitory effects (Yoon et al. 2018). This group of metabolites also improves antimicrobial activities of phenolic compounds when present together (Zhang et al. 2017). Altogether, the majority of the metabolites with antimicrobial and antivirulence properties were detected at a higher concentration in M6 extracts than in DM1 extracts and they may contribute to soft-rot and black leg resistance additively or synergistically by inhibition of plant cell-wall-degrading enzyme production or activity. Also, the biochemical assays performed using potato extracts can be a useful tool for breeders and plant pathologists to test resistance against Pectobacterium spp. and other microbes with similar modes of virulence.

\section{MATERIALS AND METHODS}

Plant materials, bacterial strains, and chemicals.

S. tuberosum (DM1) and S. chacoense (Hassl.) (M6) were grown in a greenhouse at 18 to $24^{\circ} \mathrm{C}$ with a 16-h day length. Plants were grown in ProMix Bx General Purpose mix, fertilized with Osmocote Plus 15-9-12 (Scotts-MiracleGro, U.S.A.), and irrigated to saturation every other day until used for assays. Aphids and other pests were managed with Botaniguard ES and Molt-X (BioWorks, U.S.A.), Entrust SC (Corteva, U.S.A.), Distance IGR (Valent Biosicences, U.S.A.), Judo and Azatin (OHP Inc., U.S.A.), Avid 0.15EC (Syngenta, U.S.A.), and Compass (Bayer, U.S.A.)

Tubers and 1-month old stems were used for extraction of metabolites. LC-MS-grade water, analytical-grade methanol, $\mathrm{ACN}$, and hydrochloric acid were purchased from Fisher Chemicals (Thermo Fisher Scientific, U.S.A.). P. brasiliense $\mathrm{Pb} 1692$ was used for all experiments in this study (Duarte et al. 2004). Nutrient broth (NB), agar, skim milk powder, tryptone, Congo red, and $\mathrm{NaCl}$ were purchased from Difco Laboratories (Thermo Fisher Scientific). Bacteria were grown at $30^{\circ} \mathrm{C}$ under continuous shaking conditions.

\section{Microscopy.}

One-month-old DM1 and M6 potato plants were cut at the stem base and dipped into $10 \mathrm{ml}$ of water containing RFP (p519::ntpI::ds.Red.T3)-tagged Pb1692 $\left(10^{6} \mathrm{CFU} \mathrm{ml}^{-1}\right)$ for $2 \mathrm{~h}$. A cross section of stem was taken $5 \mathrm{~cm}$ above the dipped stem mark and observed under an Olympus IX83 Inverted Spinning Disk Confocal Microscope, using an RFP filter (Olympus, Japan). 


\section{Extraction and fractionation of metabolites.}

Potato tubers and stems of both species under study were harvested, flash frozen in liquid nitrogen, and ground to a crude powder using mortar and pestle. Ground samples were lyophilized for at least $12 \mathrm{~h}$ (HarvestRight, U.S.A.). The freeze-dried stem and tuber tissues were then ground to a fine powder using a coffee grinder. For metabolite extraction, $2 \mathrm{ml}$ of 70:30 methanol/water ( $\mathrm{vol} / \mathrm{vol}$ ) was added to a $100 \mathrm{mg}$ of tissue, agitated for $2 \mathrm{~h}$ at $4^{\circ} \mathrm{C}$ using a vortexer, then sonicated for $5 \mathrm{~min}$ at room temperature. The mixture was then centrifuged at $6,000 \times g$ for $20 \mathrm{~min}$ at $4^{\circ} \mathrm{C}$ and the supernatant was transferred to a new vial and dried under a stream of nitrogen gas (Organomation Associates Inc., U.S.A.). The dry matter (the metabolite extract) was weighed for each sample to normalize the doses used in the microbial studies.

Fractionated extracts were used for some assays. Metabolites were separated based on polarity using Discovery Solid Phase Extraction (SPE) C18 columns (Sigma-Aldrich Inc., U.S.A.) with an ACN gradient between 20 and $100 \%$. SPE columns were attached to a vacuum trap, the flow rate was set at $0.5 \mathrm{ml} \mathrm{min}^{-1}$, and columns were first activated using 5\% methanol. For fractionation, the dried metabolite extracts were resuspended in 5\% methanol and run through the activated columns. The initial eluent (unretained metabolites) was discarded and the columns were again washed in 5\% methanol. After washing, a $20 \%$ ACN solution was run through the column and the eluent was collected in separate vials. Similarly, a gradient of ACN solution was used $(40,60,80$, and $100 \%$ ) for eluting the compound bound in SPE-C18 columns with the same flow rate.

\section{Bacterial multiplication and exoenzyme measurements.}

Bacterial cultures were grown overnight in $\mathrm{NB}$ at $30^{\circ} \mathrm{C}$ under continuous shaking at $220 \mathrm{rpm}$. The overnight-grown culture was centrifuged and resuspended into sterile water, which was used as a source of inoculum for studying bacterial responses to metabolite extracts. The dried metabolite extracts were resuspended in sterile water at a concentration of $10 \mathrm{mg} \mathrm{ml}^{-1}$ and bacteria were inoculated at a concentration of $10^{6} \mathrm{CFU} \mathrm{ml} l^{-1}$. Bacteria were then incubated for $15 \mathrm{~h}$ at $30^{\circ} \mathrm{C}$ under continuous shaking at $220 \mathrm{rpm}$. Bacterial multiplication was recorded at 3-h time points using a serial dilution method and results were recorded as CFU ml ${ }^{-1}$. The culture tubes were then centrifuged $(8,000 \times g, 5 \mathrm{~min})$ to separate supernatant and $\mathrm{Pb} 1692$ cells. The bacterial pellets were used for RNA extraction and supernatant was filter sterilized and used to measure AHL (using reporter strain CV026) and the exoenzyme activity: Pel, Cel, and Prt. The activity assays of these enzymes were performed in plate assays as previously described (Chatterjee et al. 1995; Vijayaraghavan and Vincent 2013). For metabolite fractions, exoenzyme activity was measured using the same procedure with $1 \mathrm{ml}$ of each M6 fraction (concentration of $5 \mathrm{mg} \mathrm{ml}^{-1}$ ) added to $10 \mathrm{mg}$ of DM1 total metabolite extractions.

\section{RNA extraction, cDNA preparation, and quantitative reverse-transcription PCR.}

The Pb1692 bacterial cell pellet was used for RNA extraction using TRIzol reagent, following the user guide (Thermo Fisher Scientific). Extracted RNA was employed to prepare cDNA using iScript cDNA synthesis kit (Bio-Rad Laboratories Inc., U.S.A.). In total, $1 \mu \mathrm{g}$ of RNA was used for cDNA preparation, following the manufacturer's instruction. The quantification of transcripts (pell and pel2 with Pel, prtl and prtE with Prt, prtW and inh with metalloprotease and Prt inhibitor, and $\sec A$ with the protein translocate subunit) was performed as previously described (Joshi et al. 2016).

\section{Detection of AHL molecules.}

C. violaceum is a gram-negative bacterium that produces a purple pigment, violacein, in the presence of AHL. The reporter strain CV026, which has a mini-Tn5 insertion in the lux I homolog, is used to detect the presence of AHL (McClean et al. 1997). This mutant strain produces purple pigment violacein in the presence of AHL compounds with $\mathrm{N}$-acyl $\mathrm{C} 4$ to $\mathrm{C} 8$ side chains. Therefore, CV026 was used to detect the level of AHL in this study.

Pcb1692 was cultured in metabolite extracts and the supernatant was separated as described above. The reporter strain CV026 was grown in fresh NB medium supplemented with kanamycin $\left(50 \mu \mathrm{g} \mathrm{ml}^{-1}\right)$. Each supernatant $(50 \mu \mathrm{l})$ was transferred to the center of nutrient agar plates inside a hole made with a 5-mm-diameter cork borer. Then, CV026 was spread with a microbial loop on four sides of the hole on the nutrient agar (Thermo Fisher Scientific) plates. The plates were incubated overnight $(18 \mathrm{~h})$ at $30^{\circ} \mathrm{C}$ and the intensity of the purple color exhibited by the reporter strain was assessed.

\section{LC-MS metabolite detection, data processing, and metabolite annotation.}

The fractions that were biologically active against Pb1692 were dried and resuspended in 50\% methanol at a concentration of $4 \mathrm{mg} \mathrm{ml}^{-1}$. The metabolomic profiling was performed on a Waters Acquity Classic ultrahigh-performance liquid chromatography system coupled to a Waters Xevo G2 time-of-flight mass spectrometer (Waters, U.S.A.). Two LCs were used for metabolite separation (in separate injections): reverse-phase chromatography (Waters Acquity CSH Phenyl Hexyl column, $1.7 \mu \mathrm{M}, 1.0 \times 100 \mathrm{~mm}$ ) (Waters) and hydrophilic interaction chromatography (HILIC) (EMD Millipore ZIC-pHILIC, $5 \mu \mathrm{M}$, $2.0 \times 150 \mathrm{~mm})($ EMD Millipore, U.S.A.). Samples were kept at $6^{\circ} \mathrm{C}$ and run in a randomized order using $3 \mu \mathrm{l}$ of injection volume. The mobile phases for reverse-phase chromatography were (A) water with $2 \mathrm{mM}$ ammonium formate and (B) ACN with $0.1 \%$ formic acid. A constant flow rate of $0.2 \mathrm{ml} \mathrm{min}^{-1}$ was used. The gradient started at $99 \% \mathrm{~A}$ and held for $1 \mathrm{~min}$, changed to $98 \%$ B over $12 \mathrm{~min}$, held at $98 \%$ B for $3 \mathrm{~min}$, then returned to $99 \%$ A over $0.05 \mathrm{~min}$ and held at $99 \%$ A for $3.9 \mathrm{~min}$. The column was held at $65^{\circ} \mathrm{C}$. The mobile phases for HILIC were (A) water with $10 \mathrm{mM}$ ammonium bicarbonate at $\mathrm{pH} 9.6$ and (B) ACN. The gradient used was as follows: time $=0 \mathrm{~min}$, $10 \%$ A, flow $=0.27 \mathrm{ml} \mathrm{min}^{-1} ; 1.5 \mathrm{~min}, 10 \% \mathrm{~A}, 0.27 \mathrm{ml} \mathrm{min}^{-1}$; $10 \mathrm{~min}, 38 \% \mathrm{~A}, 0.27 \mathrm{ml} \mathrm{min}^{-1}$; $14 \mathrm{~min}, 60 \% \mathrm{~A}, 0.24 \mathrm{ml} \mathrm{min}^{-1}$; $18 \mathrm{~min}, 80 \% \mathrm{~A}$, flow $=0.2 \mathrm{ml} \mathrm{min}{ }^{-1} ; 20 \mathrm{~min}, 95 \% \mathrm{~A}, 0.15 \mathrm{ml}$

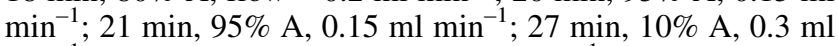

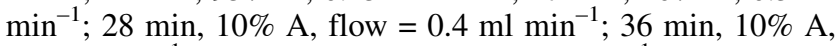
$0.4 \mathrm{ml} \mathrm{min}^{-1}$; $36.5 \mathrm{~min}, 10 \% \mathrm{~A}, 0.27 \mathrm{ml} \mathrm{min}^{-1}$; and $40 \mathrm{~min}$, $10 \% \mathrm{~A}, 0.27 \mathrm{ml} \mathrm{min}^{-1}$. The HILIC column temperature was held at $50^{\circ} \mathrm{C}$. The data were acquired in both positive and negative mode on the mass detector with electrospray capillary voltage set at $2,200 \mathrm{~V}$, source temperature at $150^{\circ} \mathrm{C}$, and nitrogen desolvation temperature at $350^{\circ} \mathrm{C}$ with a flow rate of 800 liters $\mathrm{h}^{-1}$. The detector was scanned over 50 to $1,200 \mathrm{~m} / \mathrm{z}$ at 0.2 s/scan, alternating between MS ( $6 \mathrm{~V}$ collision energy) and MSE mode (15 to $30 \mathrm{~V}$ ramp). Calibration was performed using sodium iodide with $1 \mathrm{ppm}$ mass accuracy. Quality control was performed by running quality control samples after every six experimental samples using a pooled sample approach, as previously described (Broadhurst et al. 2018).

For data processing, .RAW files were converted to .cdf format and processed as previously described (Yao et al. 2019) in R statistical software (R Core Team 2015). Briefly, peak detection, grouping, alignment, and filling were performed using XCMS in R (Smith et al. 2006), then deconvoluted and normalized to total ion current using the RAMClust package in $\mathrm{R}$ (Broeckling et al. 2014). Interpretation of spectra occurred using the R package Interpret MS spectrum and MS-Finder v3.0 (Lai et al. 2018; Tsugawa et al. 2016), which determined 
molecular weights of fragments, chemical formulas, and structures, which were eventually searched and matched using external MS databases and tools such as METLIN (Montenegro-Burke et al. 2020), MetFrag (Wolf et al. 2010), and NIST library (Mikaia et al. 2014).

\section{Statistical analysis.}

Bacterial multiplication, exoenzyme, and gene expression data were analyzed with JMP-Pro software (version 5.0; SAS Institute Inc., U.S.A.) using Student's $t$ tests to compare between treatments, with a $P$ threshold of 0.05 . Metabolomics data were analyzed in SIMCA software (version 15.0; Umetrics, Umea, Sweden) for PCA of spectral clusters using unit variance scaling. FC for metabolites was calculated using the mean relative abundance value of each M6 metabolite compared with the mean DM1 abundance for the same metabolite. All graphs were illustrated using Graph Pad Prism 8.

\section{LITERATURE CITED}

Abdou, R., Shabana, S., and Rateb, M. E. 2020. Terezine E, bioactive prenylated tryptophan analogue from an endophyte of Centaurea stoebe. Nat. Prod. Res. 34:503-510.

Bai, J., Wu, Y., Liu, X., Zhong, K., Huang, Y., and Gao, H. 2015. Antibacterial activity of shikimic acid from pine needles of Cedrus deodara against Staphylococcus aureus through damage to cell membrane. Int. J. Mol. Sci. 16:27145-27155.

Borges, A., Ferreira, C., Saavedra, M. J., and Simões, M. 2013. Antibacterial activity and mode of action of ferulic and gallic acids against pathogenic bacteria. Microb. Drug Resist. 19:256-265.

Bouarab-Chibane, L., Forquet, V., Lantéri, P., Clément, Y., LéonardAkkari, L., Oulahal, N., Degraeve, P., and Bordes, C. 2019. Antimicrobial properties of polyphenols: Characterization and QSAR (quantitative structure-activity relationship) models. Front. Microbiol. 10:829.

Broadhurst, D., Goodacre, R., Reinke, S. N., Kuligowski, J., Wilson, I. D., Lewis, M. R., and Dunn, W. B. 2018. Guidelines and considerations for the use of system suitability and quality control samples in mass spectrometry assays applied in untargeted clinical metabolomic studies. Metabolomics 14:72.

Broeckling, C. D., Afsar, F. A., Neumann, S., Ben-Hur, A., and Prenni, J. E. 2014. RAMClust: A novel feature clustering method enables spectralmatching-based annotation for metabolomics data. Anal. Chem. 86: 6812-6817.

Chaparro, J. M., Holm, D. G., Broeckling, C. D., Prenni, J. E., and Heuberger, A. L. 2018. Metabolomics and ionomics of potato tuber reveals an influence of cultivar and market class on human nutrients and bioactive compounds. Front. Nutr. 5:36.

Charkowski, A., Blanco, C., Condemine, G., Expert, D., Franza, T., Hayes, C., Hugouvieux-Cotte-Pattat, N., López Solanilla, E., Low, D., Moleleki, L., Pirhonen, M., Pitman, A., Perna, N., Reverchon, S., Rodríguez Palenzuela, P., San Francisco, M., Toth, I., Tsuyumu, S., van der Waals, J., van der Wolf, J., Van Gijsegem, F., Yang, C. H., and Yedidia, I. 2012. The role of secretion systems and small molecules in soft-rot Enterobacteriaceae pathogenicity. Annu. Rev. Phytopathol. 50:425-449.

Charkowski, A. O. 2018. The changing face of bacterial soft-rot diseases. Annu. Rev. Phytopathol. 56:269-288.

Chatterjee, A., Cui, Y., Liu, Y., Dumenyo, C. K., and Chatterjee, A. K. 1995. Inactivation of rsmA leads to overproduction of extracellular pectinases, cellulases, and proteases in Erwinia carotovora subsp. carotovora in the absence of the starvation/cell density-sensing signal, N-(3-oxohexanoyl)L-homoserine lactone. Appl. Environ. Microbiol. 61:1959-1967.

Christhudas, I. V. S. N., Kumar, P. P., and Agastian, P. 2012. Antimicrobial activity and HPLC analysis of tropane alkaloids in Streptomyces spp. isolated from Datura stramonium L. Asian J. Pharm. Clin. Res. 5: 278-282.

Chung, Y. S., Kim, C., and Jansky, S. 2017. New source of bacterial soft rot resistance in wild potato (Solanum chacoense) tubers. Genet. Resour. Crop Evol. 64:1963-1969.

Compean, K. L., and Ynalvez, R. A. 2014. Antimicrobial activity of plant secondary metabolites: A review. Res. J. Med. Plant 8:204-213.

Cushnie, T. P. T., Cushnie, B., and Lamb, A. J. 2014. Alkaloids: An overview of their antibacterial, antibiotic-enhancing and antivirulence activities. Int. J. Antimicrob. Agents 44:377-386.
Czajkowski, R., Pérombelon, M. C. M., van Veen, J. A., and van der Wolf, J. M. 2011. Control of blackleg and tuber soft rot of potato caused by Pectobacterium and Dickeya species: A review. Plant Pathol. 60 999-1013.

de Kievit, T. R., and Iglewski, B. H. 2000. Bacterial quorum sensing in pathogenic relationships. Infect. Immun. 68:4839-4849.

Duarte, V., de Boer, S. H., Ward, L. J., and de Oliveira, A. M. 2004. Characterization of atypical Erwinia carotovora strains causing blackleg of potato in Brazil. J. Appl. Microbiol. 96:535-545.

Friedman, M. 2006. Potato glycoalkaloids and metabolites: Roles in the plant and in the diet. J. Agric. Food Chem. 54:8655-8681.

Guimarães, A. C., Meireles, L. M., Lemos, M. F., Guimarães, M. C. C. Endringer, D. C., Fronza, M., and Scherer, R. 2019. Antibacterial activity of terpenes and terpenoids present in essential oils. Molecules 24:2471.

Hildenbrand, S., and Ninnemann, H. 1994. Kinetics of phytoalexin accumulation in potato tubers of different genotypes infected with Erwinia carotovora ssp atroseptica. Physiol. Mol. Plant Pathol. 44: 335-347.

Hussain, M., Debnath, B., Qasim, M., Bamisile, B. S., Islam, W., Hameed, M. S., Wang, L., and Qiu, D. 2019. Role of saponins in plant defense against specialist herbivores. Molecules 24:2067.

Jakubczyk, D., and Dussart, F. 2020. Selected fungal natural products with antimicrobial properties. Molecules 25:911.

Jansky, S., Navarre, R., and Bamberg, J. 2019. Introduction to the special issue on the nutritional value of potato. Am. J. Potato Res. 96:95-97.

Joshi, J. R., Burdman, S., Lipsky, A., Yariv, S., and Yedidia, I. 2016. Plant phenolic acids affect the virulence of Pectobacterium aroidearum and P. carotovorum ssp. brasiliense via quorum sensing regulation. Mol Plant Pathol. 17:487-500.

Joshi, J. R., Burdman, S., Lipsky, A., and Yedidia, I. 2015. Effects of plant antimicrobial phenolic compounds on virulence of the genus Pectobacterium. Res. Microbiol. 166:535-545.

Joshi, J. R., Khazanov, N., Khadka, N., Charkowski, A. O., Burdman, S., Carmi, N., Yedidia, I., and Senderowitz, H. 2020. Direct binding of salicylic acid to Pectobacterium N-acyl-homoserine lactone synthase. ACS Chem. Biol. 15:1883-1891.

Keymanesh, K., Soltani, S., and Sardari, S. 2009. Application of antimicrobial peptides in agriculture and food industry. World J. Microb. Biot. 25:933-944.

Khadka, N., Joshi J. R., Reznik, N., Chriker, N., Nudel, A., Zelinger, E., Kerem, Z., and Yedidia I. 2020. Host specificity and differential pathogenecity of Pectobacterium strains from dicot and monocot hosts. Microrganisms 8:1479.

Lai, Z., Tsugawa, H., Wohlgemuth, G., Mehta, S., Mueller, M., Zheng, Y., Ogiwara, A., Meissen, J., Showalter, M., Takeuchi, K., Kind, T., Beal, P., Arita, M., and Fiehn, O. 2018. Identifying metabolites by integrating metabolome databases with mass spectrometry cheminformatics. Nat. Methods 15:53-56.

Leisner, C. P., Hamilton, J. P., Crisovan, E., Manrique-Carpintero, N. C., Marand, A. P., Newton, L., Pham, G. M., Jiang, J., Douches, D. S., Jansky, S. H., and Buell, C. R. 2018. Genome sequence of M6, a diploid inbred clone of the high-glycoalkaloid-producing tuber-bearing potato species Solanum chacoense, reveals residual heterozygosity. Plant J. 94:562-570.

Levy, D., and Veilleux, R. E. 2007. Adaptation of potato to high temperatures and salinity-a review. Am. J. Potato Res. 84:487-506.

Li, L., Yuan, L., Shi, Y., Xie, X., Chai, A., Wang, Q., and Li, B. 2019. Comparative genomic analysis of Pectobacterium carotovorum subsp. brasiliense SX309 provides novel insights into its genetic and phenotypic features. BMC Genomics 20:486.

Liu, H., Coulthurst, S. J., Pritchard, L., Hedley, P. E., Ravensdale, M., Humphris, S., Burr, T., Takle, G., Brurberg, M.-B., Birch, P. R. J., Salmond, G. P. C., and Toth, I. K. 2008. Quorum sensing coordinates brute force and stealth modes of infection in the plant pathogen Pectobacterium atrosepticum. PLoS Pathog. 4:e1000093.

Liu, Y., Cui, Y., Mukherjee, A., and Chatterjee, A. K. 1997. Activation of the Erwinia carotovora subsp. carotovora pectin lyase structural gene pnlA: A role for RdgB. Microbiol. Read. 143:705-712.

López-Gresa, M. P., Torres, C., Campos, L., Lisón, P., Rodrigo, I., Bellés, J. M., and Conejero, V. 2011. Identification of defence metabolites in tomato plants infected by the bacterial pathogen Pseudomonas syringae. Environ. Exp. Bot. 74:216-228.

Lou, Z., Wang, H., Rao, S., Sun, J., Ma, C., and Li, J. 2012. p-Coumaric acid kills bacteria through dual damage mechanisms. Food Control 25: 550-554.

Ma, B., Hibbing, M. E., Kim, H. S., Reedy, R. M., Yedidia, I., Breuer, J., Breuer, J., Glasner, J. D., Perna, N. T., Kelman, A., and Charkowski, A. O. 2007. Host range and molecular phylogenies of the soft rot enterobacterial genera Pectobacterium and Dickeya. Phytopathology 97:1150-1163. 
Mansfield, J., Genin, S., Magori, S., Citovsky, V., Sriariyanum, M., Ronald, P., Dow, M., Verdier, V., Beer, S. V., Machado, M. A., Toth, I., Salmond, G., and Foster, G. D. 2012. Top 10 plant pathogenic bacteria in molecular plant pathology. Mol. Plant Pathol. 13:614-629.

McClean, K. H., Winson, M. K., Fish, L., Taylor, A., Chhabra, S. R., Camara M., Daykin, M., Lamb, J. H., Swift, S., Bycroft, B. W., Stewart, G. S., and Williams, P. 1997. Quorum sensing and Chromobacterium violaceum: Exploitation of violacein production and inhibition for the detection of Nacylhomoserine lactones. Microbiol. Read. 143:3703-3711.

Mikaia, A., White, E. V., Zaikin, V., Zhu, D., Sparkman, O. D., Neta, P., Zenkevich, I., Linstrom, P., Mirokhin, Y., and Tchekhovskoi, D. 2014. NIST standard reference database 1A. Standard Reference Data, NIST, Gaithersburg, MD, U.S.A. https://www.nist.gov/srd/nist-standard-referencedatabase-1a

Montenegro-Burke, J. R., Guijas, C., and Siuzdak, G. 2020. METLIN: A tandem mass spectral library of standards. Methods Mol. Biol. 2104: 149-163.

Motyka, A., Zoledowska, S., Sledz, W., and Lojkowska, E. 2017. Molecular methods as tools to control plant diseases caused by Dickeya and Pectobacterium spp.: A minireview. N. Biotechnol. 39 (Pt B):181-189.

Muñoz-Cazares, N., García-Contreras, R., Pérez- López, M., and CastilloJuárez, I. 2017. Phenolic compounds with anti-virulence properties. IntechOpen doi:10.5772/66367

Nikoo, M., Regenstein, J. M., and Hassan, A. G. 2018. Antioxidant and antimicrobial activities of (-)-epigallocatechin-3-gallate (EGCG) and its potential to preserve the quality and safety of foods. Compr. Rev. Food Sci. Food Saf. 17:732-753.

Othman, L., Sleiman, A., and Abdel-Massih, R. M. 2019. Antimicrobial activity of polyphenols and alkaloids in middle eastern plants. Front. Microbiol. 10:911.

Paz, M. M., and Veilleux, R. E. 1999. Influence of culture medium and in vitro conditions on shoot regeneration in Solanum phureja monoploids and fertility of regenerated doubled monoploids. Plant Breed. 118: 53-57.

Pérombelon, M. C. M. 2002. Potato diseases caused by soft rot erwinias: An overview of pathogenesis. Plant Pathol. 51:1-12.

Petersson, E. V., Arif, U., Schulzova, V., Krtková, V., Hajšlová, J., Meijer, J., Andersson, H. C., Jonsson, L., and Sitbon, F. 2013. Glycoalkaloid and calystegine levels in table potato cultivars subjected to wounding, light, and heat treatments. J. Agric. Food Chem. 61:5893-5902.

Radulović, N. S., Blagojević, P. D., Stojanović-Radić, Z. Z., and Stojanović, N. M. 2013. Antimicrobial plant metabolites: Structural diversity and mechanism of action. Curr. Med. Chem. 20:932-952.

Raybaudi-Massilia, R. M., Mosqueda-Melgar, J., and Martín-Belloso, O. 2009. Antimicrobial activity of malic acid against Listeria monocytogenes, Salmonella enteritidis and Escherichia coli O157:H7 in apple, pear and melon juices. Food Control 20:105-112.

R Core Team. 2015. R: A Language and Environment for Statistical Computing. R Foundation for Statistical Computing, Vienna, Austria.
Robertson, W. M., Lyon, G. D., and Henry, C. E. 1985. Modification of the outer surface of Erwinia carotovora ssp. atroseptica by the phytoalexin rishitin. Can. J. Microbiol. 31:1108-1112.

Silva, L. N., Zimmer, K. R., Macedo, A. J., and Trentin, D. S. 2016. Plant natural products targeting bacterial virulence factors. Chem. Rev. 116 9162-9236.

Smith, C. A., Want, E. J., O’Maille, G., Abagyan, R., and Siuzdak, G. 2006. XCMS: Processing mass spectrometry data for metabolite profiling using nonlinear peak alignment, matching, and identification. Anal. Chem. 78:779-787.

Soetan, O., Oyekunle, M. A., Aiyelaagbe, O. O., and Fafunso, M. A. 2006. Evaluation of the antimicrobial activity of saponins extract of Sorghum bicolor L. Moench. Afr. J. Biotechnol. 5:2405-2407.

The Potato Genome Sequencing Consortium. 2011. Genome sequence and analysis of the tuber crop potato. Nature 475:189-195.

Tsugawa, H., Kind, T., Nakabayashi, R., Yukihira, D., Tanaka, W., Cajka, T., Saito, K., Fiehn, O., and Arita, M. 2016. Hydrogen rearrangement rules: Computational MS/MS fragmentation and structure elucidation using MS-FINDER software. Anal. Chem. 88:7946-7958.

Verghese, R. J., Mathew, S. K., and David, A. A. 2017. Antimicrobial activity of vitamin C demonstrated on uropathogenic Escherichia coli and Klebsiella pneumoniae. J. Curr. Res. Sci. Med. 3:88-93.

Vijayaraghavan, P., and Vincent, S. G. P. 2013. A simple method for the detection of protease activity on agar plates using bromocresolgreen dye. J. Biochem. Technol. 4:628-630.

Wang, S., Alseekh, S., Fernie, A. R., and Luo, J. 2019. The structure and function of major plant metabolite modifications. Mol. Plant 12: 899-919.

Wolf, S., Schmidt, S., Müller-Hannemann, M., and Neumann, S. 2010. In silico fragmentation for computer assisted identification of metabolite mass spectra. BMC Bioinf. 11:148.

Yao, L., Sheflin, A. M., Broeckling, C. D., and Prenni, J. E. 2019. Data processing for GC-MS- and LC-MS-based untargeted metabolomics. Methods Mol. Biol. 1978:287-299.

Yedidia, I., Schultz, K., Golan, A., Gottlieb, H. E., and Kerem, Z. 2019. Structural elucidation of three novel kaempferol O-tri-glycosides that are involved in the defense response of hybrid Ornithogalum to Pectobacterium carotovorum. Molecules 24:2910.

Yoon, B. K., Jackman, J. A., Valle-González, E. R., and Cho, N.-J. 2018. Antibacterial free fatty acids and monoglycerides: Biological activities, experimental testing, and therapeutic applications. Int. J. Mol. Sci. 19:1114.

Zhang, H., Dudley, E. G., and Harte, F. 2017. Critical synergistic concentration of lecithin phospholipids improves the antimicrobial activity of eugenol against Escherichia coli. Appl. Environ. Microbiol. 83:e01583-17.

Zhang, L., Benz, R., and Hancock, R. E. W. 1999. Influence of proline residues on the antibacterial and synergistic activities of $\alpha$-helical peptides. Biochemistry 38:8102-8111. 